Vesa Haapala and Riikka Rossi

\title{
Open Borders and Aliens of Art - Finnish Literature in the Literary Atlas
}

"There are no aliens in art", said Constantin Brancusi to André Breton after Breton had just introduced Tristan Tzara to him by saying that "Tzara comes from Zürich." Brancusi's phrase illustrates well what we often think of modern art and literature: they not only challenge linguistic or generic conventions, but also cultural limits. But even if we are to believe that there are no national limits in modern art, we still feel that there are some cultural constants that distinguish different literatures, such as Finnish literature.

In recent research much attention has been paid to the international dimensions of our literature. Several scholars have emphasised the ongoing interaction between different literary repertoires, generic models, ideas and themes, myths and symbols. The value of European literature has been shown to be great both in the birth and in the modernization of Finnish culture. One could state that this is a common story of any culture. However, it is worthwhile to remember some historical facts concerning our literature. Until the 19th century, there was no Finnish literary culture to speak of in the true sense of the word; before that, the culture of Finland was for the most part that of Sweden, apart from translated religious texts and the folk culture that existed in oral form. Quite dramatic transitions have occurred in less than two hundred years, and this makes our culture special.

This issue will introduce different methodological approaches to our literature from different periods. The dramas, novels, and poems analysed in the articles highlight the usual position of Finnish literature: on national and international borders. Jyrki Nummi examines how Aleksis Kivi's use of biblical allusions and other intertextual devices in Kihlaus (The Betrothal), an early masterpiece in Finnish drama from 1866, stems from the plays of William Shakespeare. Kivi lacked predecessors in the history of Finnish language, and he was to find writing models outside Finnish literature and to translate them to his own language. Mari Hatavara interprets the narration techniques of Fredrika Runeberg and Zacharias Topelius, two early 19th-century Finnish novelists, and shows how these authors writing in Swedish were contemporaries of great European writers, like Austen, Balzac and Flaubert, in their use of free indirect discourse. Anna Hollsten explains how Finnish modernist Bo Carpelan makes use of ekphrasis 
in his texts. Carpelan's poems and novels refer constantly to paintings of Cezanne and other modernist authors in pursuit of new ways of writing.

On the other hand, despite the striking internationality, universal genres and supranational cultural structures, Finnish Literature tells a strong story of its own. In Finland the concept of "national literature" contains a special shade of meaning, since the founding of Finnish literature was firmly rooted in the rising of the nation. The idea of "Finnish literature" was deliberately invented for the purposes of the 19th -century nationalist movement. Literature written in Finnish was - to adapt Benedict Anderson - to construct an imagined community called Finland and strengthen the sense of Finnish identity.

The role of Finnish literature as a national, collective experience can indeed not be discarded. Since the works of F. E. Sillanpää and Väinö Linna, Finnish narratives have established a space for sharing experiences and national traumas. The processing of the shocking events of the 1918 Civil War or the losses of the Second World War is carried over even by the younger generations that were never themselves involved in the past upheavals. A number of contemporary authors, such as Kjell Westö, Juha Seppälä, Lars Sund and Antti Tuuri, engage in relating the tale of the Finnish nation.

However, in the world of global relations and virtual reality, the national history needs to be configured in a new form. The concept of the "nation" can be transformed to the problematic of the "welfare state" that is a current theme in Leena Lehtolainen's crime fiction, as Andrew Nestingen suggests in his article. On the other hand, in contemporary literature the national history is constantly set in a new critical light and reworked through parodical and ironical strategies of representation. The old, established literary conventions are contested by strategies of metafiction and the use of marginal points of view as it is shown in the essay by Mika Hallila and Samuli Hägg. On the other hand, the parodist style and a longing for an imagined nation imply common issues. As Linda Hutcheon has pointed out, nostalgia and irony can both be seen as key components of contemporary culture today - they have even become an obsession of both mass culture and high art.

One way to strengthen the national literature is to publish critical editions of distinguished classics. Finnish scholars are known as active editors of international literature and other documents from papyrus fragments to Biblical texts. Despite the active text-critical research from exegetics to philology, scholars in Finnish literature, however, have only sporadically published scholarly editions. Last year The Finnish Literature Society started a new research and publishing unit EDITH - Critical editions of Finnish literature. Its long-term objective is to create a continually growing series of critical editions of Finnish classics. Similar to the French Bibliothéque de la Plèiade, it will not be limited to one writer, but will become a varied series of editions that will be standard sources for researchers, teachers and other readers. Editions help to mediate classics for 
contemporary readers, to bring treasures in the archives within reach of everyone, and even to promote translating, artistic direction and rendering.

Despite the richness and versatility of contemporary literary studies in Finland proved by the present issue - the Finnish Literature is not a closed case, but will serve a number of future researchers. Every generation needs to write a history of its own, and on the other hand, the global world will ensure that the treasure chest of literary topics and themes will not empty. A Finnish-Swedish poet Gunnar Björling wrote: "Historia - att skrivas på nytt. Alltid." "History - it has to be rewritten. Always." 